\title{
ПСИХОЛОГІЧНИЙ СУПРОВІД ТРАНСФОРМАЦІЙНИХ ПРОЦЕСІВ В УКРАÏHСЬКОМУ СУСПІЛЬСТВІ ТА ОСВІТІ
}

Наукова доповідь на загальних зборах НАПН України 17 грудня 2019 р.

https://doi.org/10.37472/2707-305X-2019-1-1-1-1

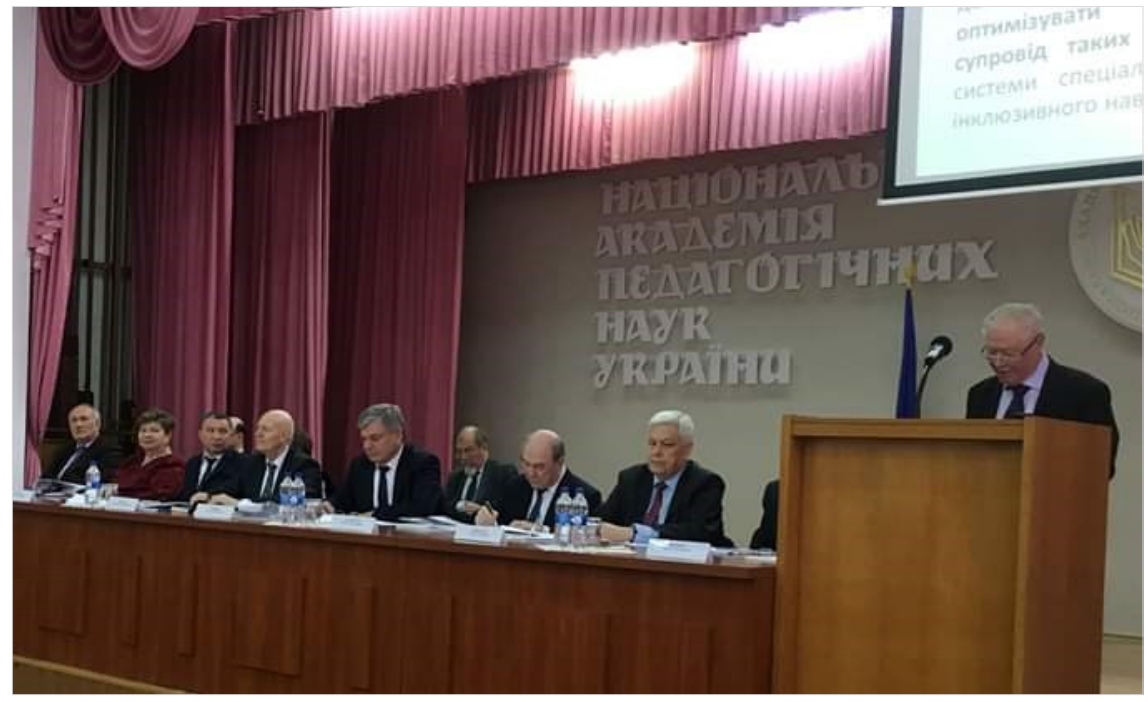

МАКСИМЕНКО Сергій Дмитрович доктор психологічних наук, просресор, дійсний член (академік) НАПН України, академік-секретар Відділення психології, вікової фрізіології ma дефектології Національної академії педагогічних наук України; директор Iнституту психології імені Г.С. Костюка Національної академії педагогічних наук України, м. Київ, Україна

Анотація. Представлено основні положення доповіді, проголошеної автором на загальних зборах НАПН України 17 грудня 2019 р. Дані положення розкривають результати фундаментальних і прикладних досліджень з означеної проблеми, які здійснюються співробітниками наукових установ, що входять до Відділення психології, вікової фізіології та десектології НАПН України. Проаналізовано такі актуальні питання: сутність трансформаційних процесів в українському суспільстві та освіті і роль психологічного супроводу в їх забезпеченні; проблеми психічного розвитку особистості та психологічного супроводу освітніх прочесів; проблеми психологічного супроводу учасників бойових дій, сімей загиблих, тимчасово переміщених осіб та їніх дітей; психологічний супровід суспільних змін; психологічний супровід дітей з особливими освітніми потребами, запровадження інклюзії у закладах освіти. Розкрито завдання та результати наукових та освітніх проєктів, основні публікації, тренінгові та консультативні практики, різноманітні напрями та форми взаємодії з представниками освітніх, державних установ, міжнародних організацій тощо.

Ключові слова: українське суспільство; освіта; трансформаційні процеси; психологічний супровід; напрями психологічного супроводу.

Шановні учасники зборів і запрошені!

Передусім хотів би наголосити на винятковій актуальності і своєчасності питання, винесеного сьогодні на загальні збори НАПН України.

у своїй доповіді я хочу зупинитися на таких важливих питаннях:

1. Сутність трансформаційних процесів в українському суспільстві та освіті і роль психологічного супроводу в їх забезпеченні.

2. Проблеми психічного розвитку особистості та психологічного супроводу освітніх процесів.

3. Проблеми психотравматизації і психо- логічного супроводу учасників бойових дій, сімей загиблих, тимчасово переміщених осіб та їхніх дітей.

4. Психологічний супровід суспільних змін.

5. Психологічний супровід дітей з особливими освітніми потребами, запровадження інклюзії у закладах освіти.

6. Висновки та рекомендації.

Послідовно розглянемо означені питання.

сутність трансорормачійних прочесів в українському суспільстві та освіті і роль психологічного супроводу в їх забезпеченні 
Здобувши державну незалежність, Україна вже майже три десятиріччя проходить складний і неоднозначний, позначений багатьма драматичними колізіями період суспільних трансформацій. Сутність трансформаційних процесів, що відбуваються в Україні, як відомо, полягає в переході від тоталітаризму до демократії, від адміністративнокомандної системи економіки до цивілізованих ринкових відносин, від всеохоплюючої несвободи, притаманної радянській добі, до вільного розвитку та самореалізації кожної людини, утвердження ії̈ особистісної і національної гідності.

Оскільки суспільні трансформації потребують, насамперед, розвитку людського потенціалу, ключову і дедалі значущішу роль у їх здійсненні відіграє національна освіта - найбільша гуманітарна сфера суспільства. Це, у свою чергу, спонукає до глибоких трансформацій і саму освіту. Незважаючи на всі труднощі та прорахунки, державна освітня політика здійснюється в напрямі якомога повнішого врахування спектру внутрішніх і зовнішніх викликів, тенденцій європейської інтеграції і світової глобалізації. Сучасна освіта має створити умови для повноцінного психічного і соціального розвитку дітей та молоді не тільки і не стільки для засвоєння певної системи знань, для її подальшого саморозвитку й самовизначення, що забезпечуватиме успішну адаптацію до мінливих умов ринку праці, цивілізаційних і культурних вимог суспільства, розвиток упродовж усього життя (lifelong development).

Ускладнення суспільного життя, нові виклики сьогодення актуалізували потребу у важливій соціальній практиці психологічного супроводу практиці надання професійної допомоги (підтримки) особам, у яких виникає дефіцит власних компетентностей, необхідних для вирішення конкретних задач життєдіяльності (спілкування, взаємодії, організації), пов'язаних з актуалізацією психологічних здібностей і здатностей.

Головним рушієм суспільних перетворень, зрозуміло, є люди - з усіма їхніми пристрастями, прагненнями, розчаруваннями та надіями. Тобто з усім тим, що перебуває в компетенції психологічної науки. I саме тому без належного психологічного супроводу успіх перетворень у суспільстві та освіті $\epsilon$ вельми проблематичним, а подекуди й апріорі неможливим. Сьогодні розвиток вітчизняної психологічної науки тісно пов'язаний із упровадженням її надбань у соціальну і педагогічну практику.
Проблеми психічного розвитку особистості mа психологічного супроводу освітніх прочесів

Одним із пріоритетних напрямів наукових досліджень науковців Відділення психології, вікової фізіології та дефектології постають проблеми психічного розвитку особистості та психологічного супроводу освітніх процесів, що забезпечує оволодіння власною поведінкою, формування системи внутрішньої регуляції діяльності, здатність людини до саморозвитку та самореалізації. Дослідження цієї проблематики відкриває дієві шляхи до поєднання теоретичних здобутків психології із соціальними запитами на модернізацію системи освіти в контексті нових реалій, зокрема психологічного забезпечення реалізації концепції Нової української школи, що дозволяє досягти мети побудови системи психологічної підтримки особистісного розвитку.

Крізь призму ідей Л.С. Виготського, у рамках культурно-історичної парадигми під керівництвом директора Інституту психології імені Г.С. Костюка НАПН України академіка НАПН України С.Д. Максименка були проведені дослідження, які показали, що генетичний, генетикомоделюючий підхід, який передбачає аутостимуляцію і відносну (у рамках моделі) свободу вибору, є найбільш ефективним у дослідженні розвитку особистості. Застосування їх у медичній, дитячій, педагогічній та віковій психологіях дозволило не лише отримати принципово нові унікальні факти, а й реально впроваджувати результати в практику навчання і виховання. Системне і рефлексивне лонгітюдне застосування методів призвело до можливості і необхідності створення нового методу, який би не обмежував людину рамками моделі, - генетико-креативного методу, що демонструє створення суб'єктом не моделі, а дійсного, реального власного світу.

Вагомий внесок у розвиток здібностей і талантів здобувачів освіти, формування соціально зрілої та соціально компетентної особистості, в реалізацію освітніх реформ, захист психічного здоров'я учасників освітнього процесу здійснює психологічна служба у системі освіти (1991р.), яка $є$ одним із найвагоміших досягнень реформування галузі за всі роки існування незалежної України. У психологічній службі системи освіти за 28 років існування вибудувано чітку вертикаль методичного підпорядкування і сформовано нормативноправову базу. Така своєрідність методичного підпорядкування забезпечує службі значний інноваційний потенціал, створює можливості для впро- 
вадження великих за кількістю учасників та масштабом територій соціальних проєктів в освіті. За даними МОН України, у 2018-2019 навчальному році кількість фахівців психологічної служби становила понад 23 тис. осіб. Загалом забезпеченість практичними психологами, соціальними педагогами у закладах освіти становить 57 \%.

Важливу роль у структурі діяльності і психологічної служби освіти України відіграє Український науково-методичний центр практичної психології і соціальної роботи (директор - професор В.Г. Панок). Центр $є$ науково-дослідною установою, яка здійснює прикладні дослідження у галузі практичної психології і соціальної педагогіки, науково-методичне керівництво, контроль і забезпечення діяльності психологічної служби у системі освіти України шляхом упровадження у педагогічну практику новітніх наукових розробок, методів і технологій.

Варто сказати, що завдяки систематичній взаємодії науковців та практиків, у тому числі й Центру, на основі розробленої концепції психічного розвитку особистості визначено вимоги до психологічного супроводу неперервної освіти та алгоритм його впровадження на усіх рівнях освітнього процесу. Розроблено критерії особистісного розвитку, створено програму моніторингу психологічних проблем процесу розвитку особистості в сучасних соціокультурних умовах, визначено напрям розвитку суб'єктної готовності до діяльності в освітньому просторі.

Важливо те, що відповідно до вимог часу систематично відстежується потенціал громадської підтримки освітніх реформ. Так, на замовлення МОН України Інститутом соціальної та політичної психології НАПН України у 2017-2018 рр. (директор - член-кореспондент НАПН України М.М. Слюсаревський) проведено дослідження перших результатів пілотного впровадження концепції Нової української школи, що дало змогу внести необхідні корективи в тренінги з підготовки вчителів початкової школи. Масове опитування, що стосувалось упровадження нового Державного стандарту початкової школи, стало основою для розроблення МОН України комунікаційної компанії на його підтримку. Репрезентативні масові опитування з освітянської проблематики поєднуються із розробленням науково-дослідної тематики, присвяченої формуванню у громадській думці позитивного образу освітніх інновацій. Згідно з наказами МОН України від 4 березня 2016 р. № 219 та від 8 серпня 2017 р. № 1128 проводиться всеукраїнський експеримент за темою «Формування позитивної громадської думки щодо освітніх інновацій у загальноосвітніх закладах», проміжні результати якого є вельми обнадійливими з погляду зміни ставлення освітянської громадськості до окремих освітніх нововведень, зокрема й таких наразі не зовсім популярних, як 12-річна школа.

Здійснюється інноваційно-дослідницький проєкт «Психологічні засади розвитку соціальних компетентностей педагогічних працівників в умовах Нової української школи», який реалізується спільно Інститутом психології імені Г.С. Костюка НАПН України спільно з Державним закладом вищої освіти «Університет менеджменту освіти» та Рівненським обласним інститутом післядипломної педагогічної освіти. У рамках проєкту (керівник проєкту - член-кореспондент НАПН України Л.М. Карамушка) побудовано модель соціальних компетентностей, розроблено комплекс діагностичних методик для їх вивчення, розроблено та проведено систему тренінгових занять для управлінського персоналу та педагогічних працівників щодо розвитку соціальних компетентностей. Усього в проєкті задіяно понад 1000 педагогічних працівників закладів загальної середньої освіти.

Інститутом психології імені Г.С. Костюка НАПН України спільно з Комунальним вищим навчальним закладом Київської обласної ради «Київський обласний інститут післядипломної освіти педагогічних кадрів» реалізується інноваційний освітній проєкт регіонального рівня «Забезпечення психологічного здоров'я менеджерів та педагогічних працівників освітніх організацій в умовах Нової української школи» (наказ Департаменту освіти і науки Київської обласної державної адміністрації від 14 листопада 2017 р. № 375) (керівники - член-кореспондент НАПН України Л.М. Карамушка; кандидат психологічних наук А.М. Шевченко).

Основними науково-прикладними завдання проєкту є: побудова моделі психологічного здоров'я менеджерів і педагогічних працівників; визначення змісту та основних напрямів психологічного супроводу освітнього персоналу щодо забезпечення психологічного здоров'я; проведення сертифікаційних навчально-методичних заходів 3 підвищення кваліфікації керівників і практичних психологів закладів загальної середньої освіти у формі тренінгів; проведення індивідуальних і групових консультацій 3 керівниками та 
практичними психологами експериментальних закладів загальної середньої освіти; підготовка публікацій, проведення конференцій за результатами експериментальної роботи. Проєктом охоплено 95 закладів загальної середньої освіти.

Науковцями установ Відділення здійснюється також психологічний аналіз і психологічна експертиза освітніх програм та навчальної книги. Зокрема, в Інституті психології імені Г.С. Костюка НАПН України методично опрацьована практика: психологічного аналізу основних і додаткових навчальних програм, підручників відповідно до стандартів шкільної освіти; аналізу педагогічних інновацій, експертної оцінки нових підходів і концепцій організації освітнього простору, оцінки потенціалу та можливостей упровадження інновацій з точки зору психологічного знання.

Принципова увага у психологічних дослідженнях науковців, зокрема Інституту психології імені Г.С. Костюка НАПН України, приділяється дошкільній ланці. У межах всеукраїнського експерименту «Радість розвитку» відпрацьовуються інновації, спрямовані на визначення психологічних особливостей самореалізації дитини дошкільного віку, та розробляється система психологопедагогічних умов, які забезпечують становлення особистості дитини в ігровій і навчальній діяльності. Колектив авторів Інституту психології імені Г.С. Костюка НАПН України Т.О. Піроженко, С.О. Ладивір, О.Ю. Хартман став лауреатом Державної премії України в галузі освіти 2018 р. у номінації «Дошкільна і позашкільна освіта» за комплексну науково-прикладну роботу «Освітня технологія «Радість розвитку» - партнерська взаємодія дорослих та дітей». Крім того, разом з Інститутом проблем виховання НАПН України розроблено та запроваджується навчально-методичний комплект «Впевнений Старт», який складається 3 освітньої програми для дітей середнього і старшого дошкільного віку та методичних посібників для всіх учасників освітнього процесу. Комплект використовується в закладах освіти 12 областей України.

3 метою гарантування права дитини навчатись у безпечному освітньому просторі, забезпечення успішної взаємодії усіх суб'єктів освітнього процесу запобігання руйнівному впливові різних форм деструктивної взаємодії, таких як залякування, психологічне насилля, знущання та цькування (булінг), на психологічний клімат освітнього простору, розробляються методи подолання проявів деструктивних стратегій взаємодії учасників осві- тнього простору в усіх його сегментах на різних рівнях соціальних контактів; здійснюється напрацювання стратегій та інструментів протидії деструктивним впливам.

Так, наприклад, працівники психологічної служби прийняли майже 49 тис. запитів від учасників освітнього процесу щодо протидії домашньому насильству; близько 87 тис. запитів щодо протидії булінгу. Зокрема, з боку батьків надійшло 28 тис. звернень, з боку педагогічних працівників - 23 тис., з боку дітей - 30 тис. та з боку інших зацікавлених осіб - 5,5 тис. звернень. Щодо протидії мобінгу педагогічних працівників до психологів та соціальних педагогів надійшло 5,4 тис. звернень.

Формування навичок безконфліктного, ненасильницького спілкування, уміння розв'язувати конфлікти, формування гуманного ставлення до інших, навичок соціальної співпраці та соціальної взаємодії здійснювалось також у рамках міжнародного проєкту «Мирна школа», який одержав статус всеукраїнського експерименту і реалізується у 5 областях України та в межах програми «Сімейна розмова», яка реалізується у закладах освіти з 2011 р.

Велика увага в дослідженнях науковцівпсихологів приділяється відповідній роботі з дорослими та людьми похилого віку для створення сприятливого «антибулінгового» психологічного клімату у сім'ях на всіх вікових рівнях.

у межах напряму досліджень, спрямованих загалом на розвиток особистості в освітньому та суспільному просторі, науковцями Відділення, зокрема Інституту психології імені Г.С. Костюка НАПН України, розробляються та запроваджуються нові діагностичні та корекційні методики, технології, тренінгові програми.

Зокрема, розроблено концептуальні засади та технології проєктування дистанційного курсу навчання «Успіх», спрямованого на розвиток психологічних компетенцій життєвої успішності. Запроваджено методику психодіагностичного обстеження обдарованих дітей та молоді на різних етапах онтогенезу.

Розроблено та модифіковано критеріальноорієнтовані діагностичні методики, спрямовані на виявлення особливостей критичного мислення старшокласників і їхнього когнітивного розвитку в умовах малих груп.

Запропоновано концепцію дистанційної професійної психодіагностики та здійснено ії практичне втілення шляхом розроблення психодіагнос- 
тичного вебсайту. Створено систему методик діагностики когнітивних тенденцій розвитку сучасних школярів, що пов'язані 3 інформаційнокомунікаційними технологіями.

Апробовано технології психологопедагогічного супроводу, спрямованого на розвиток суб'єктивного благополуччя учнівської та студентської молоді шляхом формування в них еколого-психологічної компетентності. Створено систему психологічної реабілітації та ресоціалізації підлітків з девіантною поведінкою, у межах якої визначено психологічні засоби та прийоми зміни ставлення підлітків до суспільно значущих цінностей і формування соціально схвалюваної поведінки, на основі чого розроблено комплекс психодіагностичних методик, спрямованих на визначення схильності дитини до соціально дезадаптованої поведінки, виявлення ступеня ії соціальної дезадаптації.

Розроблено технології професійного самоздійснення та життєстійкості працівників освітньої галузі з урахуванням психологічних та психофізіологічних засад професійного становлення педагогів і соціальних працівників, програму психологічної підготовки персоналу освітніх закладів до розвитку організаційної культури в умовах соціальної напруженості.

Розроблено технології психологічної підготовки персоналу освітніх закладів до роботи в умовах соціального напруження, попередження та подолання професійного стресу і синдрому професійного вигорання, програму розвитку організаційної культури в умовах соціальної напруженості, які використовуються в закладах післядипломної педагогічної освіти та в «Школах успішного менеджера».

Важливою складовою психологічного супроводу освітнього процесу є сприяння інтелектуальному розвитку дітей, молоді та дорослих. Основним джерелом цього є створення інтелектуально насиченого освітнього середовища. В Інституті психології імені Г.С. Костюка НАПН України розробляються та впроваджуються відповідні технології розвитку інтелекту на всіх вікових рівнях, зокрема у широко розповсюдженій нині дистанційній формі з використанням Інтернету та соціальних мереж. Спеціальні дослідження спрямовано на формування психологічних механізмів сприймання, обробки, фільтрування, засвоювання та використання інформації різної модальності, перетворення ії на засоби вирішення завдань (професійних, особистісних та ін.). Створено також систему безкоштовних дистанційних навчально-розвивальних курсів для інтелектуальнотворчого розвитку, які використовуються для формування комунікаційної компетентності і вирішення конфліктів, розвитку суб'єктності та проєктного мислення усіх учасників освітнього процесу.

Проблеми психотравматизащії і психологічного супроводу учасників бойових дій, сімей загиблих, тимчасово переміщених осіб та їхніх dimeŭ

Сучасний етап суспільних та освітніх трансформацій обтяжений російською агресією проти України, що поглиблює соціально-економічну кризу та призводить до масової психотравматизації військовослужбовців і цивільного населення. Учасники бойових дій, сім'ї загиблих, тимчасово переміщенні особи та їхні діти - усі вони потребують психологічного супроводу, дієвої психологічної допомоги. Участь у супроводженні трансформаційних процесів, у психологічній підтримці героїв і жертв війни на сході стала тестом на професійну спроможність і громадянську зрілість для членів і наукових установ Відділення психології, вікової фізіології і дефектології НАПН України . Цей тест вони з гідністю проходять, долучаючись до практичних і теоретичних досліджень сучасних проблем.

Упродовж 5 років при Інституті психології імені Г.С. Костюка НАПН України діє Кризовий центр медико-психологічної допомоги та гаряча лінія «Телефон довіри», а при Інституті соціальної та політичної психології НАПН України - Методичний реабілітаційний центр на волонтерських засадах. До команди Центру входять психологи, які мають Європейську психотерапевтичну освіту за різними напрямами психотерапії та підготовку з кризового консультування. Ними здійснюється професійна підтримка фахівців (практичних психологів, соціальних працівників, шкільних психологів), які працюють з постраждалими в зоні АTO / OOC; профілактика травматизації та емоційного вигорання психологів-волонтерів і представників інших «допоміжних» професій; розроблення програм, методичного інструментарію, методичних рекомендацій і посібників; психологічне просвітництво населення через 3МІ; проводиться робота з групами вимушених переселенців; виїзні консультації для поранених; телефонне консультування; індивідуальна робота з дітьми біженців, сім'ями загиблих тощо. 
3 жовтня 2014 р. було укладено Договір про співпрацю між Інститутом психології імені Г.С. Костюка НАПН України та Клінікою професійних захворювань Державної установи «Інститут медицини праці імені Ю.І. Кундієва Національної академії медичних наук України», де за спільної ініціативи медиків і психологів реалізується авторська Програма «Дорога зцілення», направлена на медико-психологічну реабілітацію учасників АТО. Медико-психологічна реабілітація пацієнтів здійснюється мультидисциплінарною командою за участю лікарів, психологів та інших спеціалістів. Для кожного пацієнта розробляється індивідуальна програма реабілітації після проведення обстеження особи усіма членами команди. Основною діяльністю команди психологів $€$ проведення профілактичної, консультативно-психологічної та медико-психологічної, реабілітаційної роботи 3 військовослужбовцями, ветеранами та членами їхніх сімей, волонтерами через консультування та психотерапію, сімейне консультування. Психологічна допомога здійснюється в індивідуальній (68 сесій) та груповій (4-6 зустрічей) формах за період лікування. 32014 р. по теперішній час пройшли реабілітацію близько 1400 ветеранів і членів їхніх сімей (біля 150 осіб), було проведено 6400 індивідуальних консультацій і 300 груп.

На базі Центру використовується багаторівневий комплекс лікувальних заходів із застосуванням сучасних медико-психологічних, психотерапевтичних, медикаментозних і немедикаментозних методів; упроваджено новий метод TOMATISтерапія (нейросенсорна стимуляція), дія якого спрямована на підвищення пластичності головного мозку, стимуляції окремих його зон, що ефективно регулює механізми синдромів, які супроводжують постконтузійні стани та стресові розлади.

Основні положення роботи психолога відображено в розробленому науковцями документі - «Картка психологічного супроводу», яка $€$ внутрішнім протоколом для роботи в умовах клініки. Ця картка затверджена Міністерством соціальної політики України та рекомендована для використання в реабілітаційних установах країни (наказ від 1 червня 2018 р. № 810). У ній фіксується первинна інформація, релевантна психотерапії та консультуванню; динаміка внутрішньої картини когнітивних та емоційних процесів; протокол діагностичного обстеження та необхідних інтервенцій в тому чи іншому випадку, надаються висновки та рекомендації для подальшої психологічної роботи.
3 серпня 2019 р. було укладено також договір з Державним закладом «Госпіталь ветеранів війни «Лісова поляна» Міністерства охорони здоров'я України», де успішно реалізується Програма «Дорога зцілення» та було створено Службу інформаційно-психологічного супроводу ветеранів та їхніх родин.

Співробітники Інституту психології імені Г.С. Костюка НАПН України взяли участь в проєкті Координатора проєктів ОБСє в Україні «Допомога у реінтеграції та реабілітації населення, що постраждало внаслідок конфлікту». Підготовлено посібник «Основи реабілітаційної психології» (у 3 томах). 9 листопада 2019 р. в рамках проєкту та за підтримки Міністерства соціальної політики України відбулась конференція за темою «Психологічна допомога населенню, що постраждало внаслідок конфлікту: український та зарубіжний досвід», на якій за участі академікасекретаря Відділення С.Д. Максименка було представлено основні результати проєкту.

Важливим $€$ те, що установами Відділення налагоджено співпрацю із психологічними службами силових відомств України. В Інституті соціальної та політичної психології НАПН України спільно з Державною службою України з надзвичайних ситуацій започатковано експеримент всеукраїнського рівня з підвищення психологічної готовності суб'єктів освітнього процесу до реагування на надзвичайні ситуації. Сьогодні також за ініціативи Товариства психологів України на неформальній основі створена Міжвідомча координаційна рада державних психологічних служб. До неї увійшли представники психологічної служби системи освіти, ДСНС України, Збройних Сил України, Національної гвардії України, Державної прикордонної служби України, Національної поліції України, які у свій час були побудовані за методичної підтримки і з використанням нормативної бази психологів-освітян. Координаційна рада займається розробленням проєкту Закону України «Про надання психологічної допомоги», стандартів діяльності практичних психологів і стандартів професійної підготовки, багатьма іншими важливими для нашої держави питаннями.

Інститутом психології імені Г.С. Костюка НАПН України реалізується спільний міжнародний проєкт з Клайпедським університетом (Республіка Литва) «Сприяння соціальній інтеграції громадян, постраждалих від конфлікту на Сході України» (номер проєкту P2019-VB-UK-18). 
Проєкт спрямований на реалізацію таких завдань:

- сприяти процесу інтеграції внутрішньо переміщених осіб зі Східної України до місцевих громад;

- сприяти соціальній активності переміщених осіб, особливо жінок, зміцненню їхньої спроможності до протидії насильства щодо жінок;

- допомога місцевим органам влади та жіночим організаціям у досягненні актуальних завдань щодо жінок, миру та безпеки.

У рамках проєкту відбулись зустрічі, змістовна робота та спілкування більш ніж із 150 вимушено переселеними людьми із Криму та Донбасу, у результаті яких визначались напрями подальшої роботи, найбільш актуальні проблеми та способи надання допомоги.

Відповідаючи на запити освітян, Українським науково-методичним центром практичної психології і соціальної роботи було опитано понад 1 тис. працівників психологічних служб 3 24 областей та м. Києва. Результати моніторингу склали основу Аналітичної довідки, що була покладена в основу планування дослідної та методичної роботи науковців і керівників психологічної служби у регіонах. Проведено всеукраїнський моніторинг «Надання допомоги дітям, постраждалим від військових дій, і внутрішньо переселеним особам в діяльності психологічної служби». Метою моніторингу було вивчення стану психосоціальної допомоги дітям, постраждалим від військових дій, внутрішньо переміщеним особам у закладах освіти та аналіз труднощів і проблем, пов'язаних з цією роботою, що виникають у працівників психологічної служби. Центр здійснює розроблення методик роботи з проблеми надання соціально-педагогічної допомоги дітям і сім'ям, що опинились у складних життєвих обставинах внаслідок військових дій. Наукові працівники взяли участь у 9 міжнародних проєктах з названої проблематики. Проведено навчання більше 10 тис. працівників психологічної служби і педагогічних працівників в основному з районів, які наближені до лінії розмежування, знаходяться у п'яти кілометровій зоні і навіть з непідконтрольних територій. Проведено тренінги і консультації для понад 22 тис. учнів і їхніх батьків; підготовлено і видано відповідні методичні посібники, інші методичні матеріали, розроблені з урахуванням і на основі кращих світових практик.

\section{Психологічний супровід суспільних змін}

В Інституті соціальної та політичної психології НАПН України закладено теоретико-методологічний фундамент психологічного дослідження і супроводження суспільних змін, які відбуваються сьогодні в Україні. Його складає низка затребуваних практикою наукових теорій, моделей і концепцій. Ідеться, насамперед, про напрацювання директора Інституту, члена-кореспондента НАПН України М.М. Слюсаревсь-кого, до яких належать фундаментальна концепція методологічного простору побудови та критеріального оцінювання соціально-психологічних теорій, теорія соціальної напруженості та протестного потенціалу суспільства, прогностична модель типології та актуалізації соціально-психологічних проблем у межах культурно-історичного циклу. Ці напрацювання уможливили систематичне дослідження глобальних, макро- та мікрорівневих ситуаційних чинників, що справляють нині вплив на життєвий світ люди ни, процеси формування та прояву суб'єктного потенціалу особистості, персональної і суспільної безпеки життєдіяльності, дали змогу всебічно розкрити психологічні умови, в яких функціонує суспільство, схарактеризувати ступінь його соціально-психологічної цілісності, визначити головні вектори та перспективи розвитку.

Науковою новизною та практичною значущістю відзначається запропонована членомкореспондентом НАПН України Т.М. Титаренко теорія особистісного життєконструювання і керування ризиками (у тому числі тими, що виникають у ситуації зіткнення людини зі смертю), а також теорія відновлення психологічного здоров'я особистості. На основі цих теорій розроблено відповідні технології психологічного супроводу процесів реабілітації та реадаптації, комплексної організації психосоціальної підтримки травмованої особистості.

Нагальним потребам сьогодення відповідає створена колективом лабораторії психології мас та спільнот Інституту концепція адаптації спільноти до суспільних змін, спричинених воєнним конфліктом. На ній ґрунтуються психологічні стратегії забезпечення в спільноті ціннісного порозуміння, зміцнення громадського здоров'я, регулювання процесів внутрішньої міграції, опрацювання травматичного досвіду громади, налагодження порушеної родинної взаємодії, трансформації соціального капіталу. 
Психологічні механізми захисту дітей і молоді від деструктивного впливу інформаційного простору, протистояння інформаційній агресії в умовах гібридної війни розкрито в соціальнопсихологічній теорії кіберсоціалізації, віковій періодизації медіаризиків, таксономії медіатравми, груп-рефлексивному підході до діагностики та профілактики булінгу і кібербулінгу та інших напрацюваннях члена-кореспондента НАПН України Л.А. Найдьонової. Під їі керівництвом розроблено Концепцію впровадження медіаосвіти, першу редакцію якої Президія НАПН України схвалила ще 2010 р., а другу, оновлену - 2016 р. У Концепції визначено головні напрями розвитку медіаграмотності населення як складової інформаційної безпеки держави і супроводу системи освіти в умовах гібридної війни. У межах всеукраїнських експериментів, що здійснюються згідно 3 Програмою спільної діяльності МОН України і НАПН України, розроблено навчальні програми, посібники для вчителів і учнів, підручники для системи післядипломної педагогічної освіти, програми медіаосвітніх курсів для закладів вищої освіти, методики формування новинної грамотності, інформаційного підґрунтя соціального оптимізму і патріотизму, медіазасоби долання травми війни, розвитку критичного мислення, пізнання новітніх психологічних феноменів доби цифрової трансформації суспільства.

Успішно впроваджуються в суспільну та освітню практику наукові розробки з проблем націєтворення в умовах суспільної нестабільності, когнітивних засад розв'язання соціальних конфліктів, проявів групового свідомого і несвідомого у складних соціальних ситуаціях, суб'єктивновчинкового підходу в освіті, політико-правової свідомості та політичної картини світу сучасної молоді.

Однією з ключових складових супроводу трансформаційних процесів $€$ відображення їхньої динаміки за об'єктивними науковими показниками, що необхідно для ухвалення своєчасних і обґрунтованих політичних та управлінських рішень. 3 цією метою Інститут соціальної та політичної психології НАПН України здійснює в моніторинговому режимі всеукраїнські репрезентативні опитування, якими протягом останніх п'яти років охоплено 32,5 тис. респондентів. Отримані в ході масових опитувань дані відображають особливості сприйняття суспільством української державності, символічні уявлення та ідеологічні преференції громадян, динаміку соціальної напружено- сті в суспільстві, ступінь довіри до державних і суспільних інститутів, геополітичні орієнтації населення, рівень його громадянської компетентності та активності, участь у волонтерському русі тощо.

Психологічний супровід дітей з особливими освітніми потребами, запровадження інклюзії у закладах освіти

Психологічний супровід трансформаційних процесів в Україні безпосередньо стосується і психологічного супроводу дітей з особливими освітніми потребами, запровадження інклюзії у закладах освіти. Як відомо, стратегічна мета навчання і виховання таких дітей - це повноцінна їх інтеграція в суспільство, їхня спроможність брати участь у спільному навчально-виховному процесі та суспільному житті нарівні з однолітками з нормотиповим розвитком . Кількість таких дітей в світі щорічно збільшується. У 2016 р. частка таких дітей в загальній популяції складала 7 \%, то нині вона сягає близько 8 \%. Тож, їхня соціальна інтеграція, сприянню якої слугує психологопедагогічний супровід, є актуальною проблемою.

Супровід здійснюється мультидисциплінарною командою фахівців. Відповідно до індивідуальних особливостей для кожного учня з особливими освітніми потребами групою фахівців за участі батьків дитини складається індивідуальна програма розвитку, яка затверджується керівником закладу та переглядається двічі на рік (за потреби - частіше) з метою їі коригування.

В індивідуальній програмі розвитку зазначається кількість годин і напрями проведення корекційно-розвивальних занять, визначені фахівцями інклюзивно-ресурсних центрів з урахуванням особливостей психофізичного розвитку учня та типових навчальних планів спеціальних закладів загальної середньої освіти.

У центрі уваги учасників супроводу $є$ пізнавальна сфера; рівень розвитку мислення; сформованість навчальних навичок; розвиток мовлення; працездатність; взаємодія з однолітками; взаємодія з педагогами; поведінкова саморегуляція; наявність і характер навчальної мотивації; емоційний стан; особливості індивідуальної Я-концепції; комунікативна готовність дитини тощо.

У процесі супроводу мультидисциплінарні команди працюють з дитиною, її батьками, педагогічним колективом школи. Ефективність психолого-педагогічного супроводу забезпечується відповідними засобами діагностики та визначення індивідуальних потреб дитини, застосуванням роз- 
виткових і психокорекційних методик. На рівні держави ефективність супроводу забезпечується відповідною освітньою та соціальною політикою і реалізацією державних програм соціальної допомоги.

Водночас, існує ціла низка проблем, серед яких: відсутність методик діагностики рівня розвитку дітей та їх адаптацій для окремих категорій дітей з особливими освітніми потребами; відсутність системи психолого-педагогічного супроводу родин, які мають дітей з порушеннями розвитку; психологічна підготовка педагогічних працівників, які працюють в інклюзивних закладах освіти, до роботи з дітьми з особливими освітніми потребами.

Власне, вирішенням цих і тотожних проблем і опікується Інститут спеціальної педагогіки та психології імені Миколи Ярмаченка НАПН України (директор - академік НАПН України В.В. Засенко) Зокрема, відділом психолого-педагогічного супроводу дітей з особливими потребами розроблено методичний посібник «ABCID: скринінг поведінки» (скринінг - діагностика особливостей поведінки дітей та підлітків з порушеннями розумового розвитку), створено та апробовано Програму розвитку соціального інтелекту дошкільників з аутизмом "Світогляд», видано методичний вісник для педагогів та батьків «Бар'єри в навчанні та участі дітей з когнітивними порушеннями: особливості розвитку дітей із затримкою психічного розвитку, розладами аутичного спектру, гіперактивними розладами з дефіцитом уваги», посібники «Інклюзивне навчання за нозологіями» («Дитина з труднощами у навчанні» та «Дитина з розладами аутистичного спектра»), Програму розвитку дітей дошкільного віку із затримкою психічного розвитку від 3 до 7 років «Віконечко», навчально-методичний посібник «Стандартизація навчання школярів із порушеннями когнітивного розвитку».

Означені розробки та безпосередня співпраця науковців з практичними працівниками дають змогу відчутно оптимізувати психологічний супровід дітей особливим потребами в умовах системи спеціальних закладів й інклюзивного навчання.

У проєкті постанови загальних зборів НАПН України містяться відповідні рекомендації, які пропонуються до обговорення членами НАПН України.

Дякую за увагу!

\section{СПИСОК ВИКОРИСТАНИХ ДЖЕРЕЛ}

Максименко, С.Д. (2019). Психологічний супровід трансформаційних процесів в українському суспільстві та освіті. Педагогіка і психологія. Вісник НАПН України, (4), 5-15.

\section{PSYCHOLOGICAL SUPPORT OF TRANSFORMATION PROCESSES IN UKRAINIAN SOCIETY AND EDUCATION Scientific report at the General Meeting of the National Academy of Educational Sciences of Ukraine, December 17, 2019}

Serhii Maksymenko

DSc in Psychology, Professor, Full Member (Academician) of NAES of Ukraine, Academician Secretary of the Division of Psychology, Age Physiology and Defectology, National Academy of Educational Sciences of Ukraine; Director, G.S. Kostiuk Institute of Psychology of the National Academy of Educational Sciences of Ukraine, Kyiv, Ukraine

Abstract. The main provisions of the report, announced by the author at the General Meeting of the National Acad emy of Pedagogical Sciences of Ukraine, December 17, 2019, are presented. These provisions reveal the results of fundamental and applied research on the identified problem, carried out by employees of scientific institutions that are part of the Division of Psychology, Age Physiology and Defectology at the National Academy of Educational Sciences of Ukraine. The following topical issues are analyzed: the essence of transformation processes in Ukrainian society and education and the role of psychological support in their provision; problems of mental development of the individual and psychological support of education processes; problems of psychological support for combatants, families of the victims, temporarily displaced persons and their children; psychological support for social change; psychological support for children with special educational needs, introduction of inclusion in education institutions. The tasks and results of scientific and educational projects, major publications, training and consultative practices, various directions and forms of interaction with representatives of education, state institutions, international organizations, etc. are discussed.

Keywords: Ukrainian society; education; transformation processes; psychological support; directions of psychological support.

Дата публікації: 23 грудня 2019 р. 